\title{
WRITER'S PREFACE
}

If anyone takes the Introduction of this book as his first plunge into Heidegger, he will find the water rather cold. These pages do not pretend to be a propaedeutic to this difficult thinker. They attempt rather to formulate in as concise a statement as possible the essentials of his entire problematic. The statement is coherent but compressed. Its density may make it (for the uninitiated) obscure. The Introduction was the last part of this work to be written - perhaps it is the last part to be read. At any rate, the neophyte would be well advised to start with Chapter I.

And yet a few prefatory remarks are in order. That the time has come for a study of the problem of thought in Heidegger seems clear, for none of the interpreters has given the matter the treatment it deserves. Henri Birault's lucid article in 1950 promised a full-length analysis to follow, but unfortunately it never appeared. ${ }^{1} \mathrm{~J}$. B. Lotz's review of the problem in Heidegger's recent publications makes no pretense of being a complete study, ${ }^{2}$ and Heinrich Ott's fine book on the bearing of foundational thought upon theology leaves room for a purely philosophical treatment that examines thought precisely inasmuch as it evolves out of the early Heidegger. ${ }^{3}$

\footnotetext{
1 Henri Birault, "Existence et vérité d'après Heidegger," Revue de Melaphysique at de Morale, I (1950), pp. 35-87.

- Johann B. Lotz, S. J., "Denken und Sein nach den jüngsten Veröffentlichungen von M. Heidegger," Scholastik, XXXIII (2958), pp. 8x-97.

- Heinrich Ott, Denken und Sein, Der Weg Martin Heideggers und der Weg der Theologic (Zollikon: Evangelischer Verlag, 1959).
} 
Methodologically, the research began with a general orientation in Heidegger's thought through the secondary literature of the most authoritative interpreters, then proceeded to make a close textual analysis of all of the author's published work according to the order, not in which these works were published, but in which they were written. The result was a typewritten manuscript of more than Iroo pages, which, however abundant in detail, were tediously repetitious. Yet the method of following the author's order of composition proved so illuminating that it seemed unwise to discard it in favor of a mere synthesis of the results. In editing the original manuscript, then, we took as a working principle simply to avoid unnecessary repetition, and restricted synoptic treatment to two chapters of a more general nature: Introduction and Conclusion.

The study itself we divide along the simplest lines possible: Part I treats the early Heidegger; Part II deals with the socalled "reversal" in manner and method of the early Heidegger; Part III examines the later Heidegger. As for the rest, the effort to eliminate repetition forces us sometimes to collate texts that come from different periods, but we have done the best we can to keep the different moments of the development in their proper place.

The original research continued until "Hegel and the Greeks" (r960), 4 but in the present redaction we stop with What $E$-vokes Thought? (1952). ${ }^{5}$ The reason is not that Heidegger has said nothing of importance about the problem since I952, but for our purposes we reach with the university lectures of that year the point of diminishing returns. For the years between 1952 and I960, we have sifted out what properly concerns us and fitted it into the analysis wherever it could be accommodated best.

The author's massive work on Nietzsche, ${ }^{6}$ giving in two volumes the full text of a series of university lectures delivered at Freiburg between 1936 and I940 together with certain essays that date from 1940-I946, appeared (I96I) after these re-

- "Hegel und die Griechen," Die Gegenwart der Griechen im neweren Denken, Festschrift für Hans-Georg Gadamer zum 60. Geburtstag (Tübingen: Mohr [Siebeck], 1960), pp. 43-57. This is the text of a lecture delivered July 26, I958, and should be considered prior to "Der Weg zur Sprache," Unterwegs sur Sprache (Pfullingen: Neske, 1959), pp. 239-268. (Hereafter: US).

Was heißt Denken? (Tubingen: Niemeyer, r954). (Hereafter: WD).

- Niatssche (Pfullingen: Neske, I96I), Vols. I, II. (Hereafter: N). 
searches were concluded. It was upon these same texts that Heidegger's other Nietzsche interpretations, ${ }^{7}$ which were published earlier and hitherto had served as the basis of our own analysis, were based. This new publication, then, imposed a reconsideration of Heidegger's Nietzsche-interpretation but effected no essential alteration in the writer's understanding of it. Minor revisions have been made, however, for the sake of completeness.

Scope and style of the exposition have been determined by the writer's desire to do something scientifically sound, yet in a language intelligible to discerning students of the Englishspeaking world who approach Heidegger with some philosophical background but no specialized familiarity with his manner or his milieu. This imposes the following canons: to supply certain explanations that specialists would find superfluous; to sacrifice all embellishing subtleties for the sake of clarity and conciseness; to keep clearly in view the basic perspectives by frequent repetitions of the argument.

Heidegger's language, of course, presents a special problem of translation. We have tried, however, to avoid neologism. Except in one or two cases, the translations pretend to be nothing more than approximations, and readers who can suggest still closer approximations would render the writer a service in doing so. Even orthography is a problem, since the German uses capitals for all nouns without discrimination. On principle, we have decided to reserve capitalization for Being itself and for words that stand in its place. One exception: we capitalize There-being (Dasein) as one way of suggesting the unique relationship to Being that for Heidegger this word comports.

As far as the "critical attitude" is concerned, we are trying to understand Heidegger's notion of thought and nothing else. In analysing his interpretation of specific phenomena or of other thinkers we make no attempt whatsoever to judge whether the interpretation is satisfying or not. We try simply to let Heidegger be and thus throw light on himself. ${ }^{8}$ What critical position we ourselves take we reserve for the closing pages.

? Principally: "Nietzsches Wort: Gott ist tot," Holzwege (Frankfurt: Klostermann. 1950) pp. 193-247 (Hereafter: HW); and WD, pp. 1-78.

- This same endeavor likewise accounts for the fact that we let Heidegger speak for himself as much as possible. We restrict the citation of commentators to those instances where we are obliged to acknowledge a debt or where this is necessary for the progress of the argument. 
The writer feels that he should apologize for the impression of pedantry that the abundance of footnotes may give. Originally textual references were intended to explain to the director of the research and recall to the writer why he said what he said. We have eliminated many of them, to be sure, and combined others, but because of the dreadful difficulty in reading Heidegger (many a patriotic German has despaired), we felt that anyone desirous of facing for himself the rigors of the original might welcome here and there a few friendly spots of blood that would show him how someone else made his way over the rocks.

The reader will notice very soon that the entire work suffers from chronic hyphenitis, and pur-ists may find it an-noy-ing. With little heed for the canons of syllabification, this purely mechanical device sometimes transposes the German original (v.g. ek-sistence), sometimes is the writer's own invention to express by several words what in German is a single idea (v.g. Anwesen: coming-to-presence), sometimes calls attention to an unfamiliar meaning for a familiar word (v.g. re-collection). It is really not very often, then, that we do it out of sheer mal-ice.

One final word. The altogether central place of foundational thought in Heidegger's endeavor forces us to treat in one way or another almost all of his principal themes. There is one problem, however, that we resolutely avoid: the problem of God. This is not because there is nothing to say about God in Heidegger's thinking. On the contrary, it is because there is too much to say for it to be said merely by indirection. Besides, any study of this problem presupposes, if it is going to be serious, the very analysis that we are attempting here. We reserve the matter, then, for another day, and content ourselves for the present with the modest task of watching a thinker follow his star.

And now, the pleasant task of acknowledging, at least, the debts that one can never really pay. Accumulated over many years, they are in fact beyond number, and we must be content here with mentioning only the very heaviest of them. The writer wishes to express his profound gratitude:

to Professor Martin HeIDegGer for the criticism, encouragement and help so graciously given, and especially for the honor he does the writer in contributing to this book its preface;

to Right Reverend Monsignor Louis De Raeymaeker, Presi- 
dent, and to the entire professorial corps of the Higher Institute of Philosophy, Louvain, who by both precept and example during the writer's student years inspired him with the ideals that, however unattainable, served as model for these pages;

to Professor AlBert Dondeyne, of this same Institute, for his critical suggestions, and especially for the lecture course on "Heidegger and the Problem of Finitude" (1956), which helped the writer at a critical time to see more clearly the essentials of this difficult problematic;

to Reverend Hermann L. VAn BREDA, O.F.M., Director of the Husserl Archives, Louvain, who from the very beginning made accessible to the writer the immense resources of this world center of phenomenological research;

to Professor Max Müller (Munich), who not only by his teaching helped form significantly the writer's philosophical attitudes but first made possible his personal contact with Professor Heidegger;

to Professor Eugen Fink (Freiburg) and Professor Bernard WELTE (Freiburg), who directly and indirectly both in lecture and seminar helped the writer to a deeper understanding of the contemporary German mind;

to the Bollingen Foundation for the fellowship award that made it possible to bring this study to a conclusion;

and in the last place, because in the first place, to Professor Alphonse De Waelmens, of the Higher Institute of Philosophy, Louvain, Director of this investigation from the beginning, who, although placing his own vast erudition and critical penetration entirely at the writer's disposition, encouraged nonetheless a most complete liberty in the research, and thus knew how to be at all times and in the very best of ways the ideal pedagogue. 